\title{
Analiza oddziaływania instytucji zarządzania budżetowego na innowacyjność sektora publicznego
}

\begin{abstract}
Streszczenie
Artykuł przedstawia analizę oddziaływania wybranych instytucji zarządzania budżetowego na skłonność i zdolność jednostek sektora publicznego do tworzenia, wdrażania i upowszechniania innowacji w produkcji publicznej. Pozytywnie na innowacyjność oddziałują m.in. numeryczne reguły budżetowe, odgórny i skoncentrowany budżetowy proces decyzyjny, średniookresowe ramy budżetowe i programowy podział budżetu. Analiza stanowi podstawę oceny systemu zarządzania budżetowego w podsektorze rządowym w Polsce, który zaliczono do grupy systemów hamujących innowacyjność. Koncentracja publicznych procesów decyzyjnych w ramach procesu planowania budżetowego oraz integracja zarządzania budżetowego z innymi systemami zarządzania publicznego przy wykorzystaniu wspólnej architektury programowej zostały rekomendowane jako warunki wstępne skutecznego oddziaływania na innowacyjność sektora publicznego.
\end{abstract}

Słowa kluczowe: zarządzanie publiczne, zarządzanie budżetowe, proces budżetowy, innowacyjność sektora publicznego

Kody klasyfikacji JEL: H11, H61, O31

1 Badacz niezależny, e-mail: bartosz.a.staszewski@gmail.com, https://orcid.org/0000-0001-6986-6273 


\title{
Analysis of budgetary governance institutions as determinants of public sector innovativeness
}

\begin{abstract}
The paper analyzes how selected budgetary governance institutions can influence the motivation and capability of public sector entities to generate, implement, and diffuse innovations in public production. Numerical fiscal rules, top-down and concentrated budgetary decision-making process, medium-term budget framework and program budgeting were identified as having positive impacts. The analysis is followed by an assessment of the central government sub-sector budgetary governance system in Poland, which showed that the existing budgetary arrangements might be classified as innovation restrictive. The concentration of public decision-making within the budgetary process and integration of the budgetary governance system with other public governance systems by means of a common programmatic architecture were recommended as prerequisites for effective stimulation of public sector innovativeness.
\end{abstract}

Keywords: public governance, budgetary governance, budgetary process, public sector innovativeness

JEL Classification Codes: H11, H61, O31

Współczesne państwa działają w otoczeniu, które cechuje się dużą niepewnością i rosnącą złożonością. Koszty dostarczania dóbr i usług publicznych systematycznie rosną, natomiast możliwości zwiększania wydajności tradycyjnych źródeł dochodów publicznych są ograniczone. Zapewnienie adaptatywności i responsywności sektora publicznego na poziomie adekwatnym do skali i natury stojących przed nim wyzwań wymaga rozwijania innowacyjności.

Innowacyjność sektora publicznego kształtowana jest m.in. przez systemowe środowisko działania jednostek tego sektora, na które składają się instytucje zarządzania publicznego. Na różnych etapach cyklu innowacji instytucje te tworzyć mogą bariery zniechęcające kierowników (menedżerów) i pracowników publicznych do inicjowania działań innowacyjnych. Właściwie ukształtowane instytucje mogą natomiast synergicznie wzmacniać skłonność do podejmowania i zdolność do prowadzenia takich działań na różnych poziomach zarządzania. Prowadzenie polityki sprzyjającej innowacjom wymaga więc identyfikacji czynników, które determinują skłonność i zdolność do wdrażania innowacji w sektorze publicznym, a także ustalenia występujących pomiędzy nimi współzależności. Badania czynników systemowych stanowią więc niezbędne uzupełnienie badań czynników wewnątrzorganizacyjnych. 
Wśród czynników systemowych wyróżnić należy instytucje zarządzania budżetowego. Bodźce budżetowe i dostępność zasobów mają bowiem duży potencjał indukujący lub hamujący innowacyjność sektora publicznego. Sama innowacyjność ma także istotne znaczenie budżetowe. W warunkach ograniczeń dochodowych poszukiwanie i wdrażanie nowych, bardziej produktywnych metod organizacji produkcji publicznej umożliwia bowiem zapewnienie optymalnego wolumenu dóbr i usług publicznych bez uszczerbku dla zagregowanych wyników budżetowych.

Niniejszy artykuł zawiera omówienie wyników analizy oddziaływania instytucji zarządzania budżetowego na innowacyjność sektora publicznego. Analizę przeprowadzono na podstawie ogólnych ram teoretycznych dotyczących oddziaływania instytucji zarządzania publicznego na innowacyjność sektora publicznego, opracowanych przez Organizację Współpracy Gospodarczej i Rozwoju (Organisation for Economic Co-operation and Development - OECD, 2017). Na potrzeby analizy wybrane instytucje zarządzania budżetowego podzielono na instytucje tradycyjne i innowacyjne, a następnie zbadano pod względem ich oddziaływania na skłonność do podejmowania oraz zdolność do prowadzenia działań innowacyjnych. Zidentyfikowano także bariery, które instytucje te mogą tworzyć na poszczególnych etapach cyklu innowacji. Ustalenia analityczne wykorzystano do oceny systemu zarządzania budżetowego podsektora rządowego w Polsce.

Analiza i ocena mają charakter teoretyczny. Mimo to pozwoliły one sformułować użyteczne, w ocenie autora, ogólne ustalenia i wnioski odnoszące się do oddziaływania instytucji zarządzania budżetowego na innowacyjność sektora publicznego, a także bardziej szczegółowe rekomendacje dotyczące pożądanych kierunków rozwoju systemu zarządzania budżetowego podsektora rządowego w Polsce. Stanowić one mogą jednocześnie punkt wyjścia dla dalszych badań i analiz w tym obszarze, zwłaszcza wykorzystujących metody statystyczne.

\section{Definicja innowacji sektora publicznego}

Ogólna definicja innowacji została przyjęta przez OECD i Eurostat w Podręczniku Oslo (Oslo Manual 2018). Zgodnie z nią innowacja to nowy lub ulepszony produkt lub proces (lub ich kombinacja), który różni się znacznie od wcześniejszych produktów lub procesów jednostki i który został udostępniony potencjalnym użytkownikom (produkt) lub wprowadzony do użycia przez jednostkę (proces) (OECD, Eurostat, 2018: 20).

Innowacje w sektorze publicznym stanowią stosunkowo nową kategorię analityczną, która nie zyskała jeszcze powszechnie akceptowanej definicji. W nawiązaniu do Podręcznika Oslo OECD charakteryzuje innowację w sektorze publicznym, odwołując 
się do kryteriów nowości, faktycznego wdrożenia i użyteczności. W ustalonym kontekście jest to nowe podejście, sposób lub metoda działania, które zostały wdrożone w celu dostarczania lepszych rezultatów, tj. np. wyższej efektywności, skuteczności, produktywności czy satysfakcji użytkownika lub pracownika (OECD, 2015: 14).

W Polsce do definicji z Podręcznika Oslo odwołał się Główny Urząd Statystyczny (GUS). Na potrzeby eksperymentalnego badania innowacji w wybranych jednostkach administracji publicznej GUS doprecyzował tę definicję, przyjmując, że produkty obejmują wyroby (np. publikacje lub oprogramowanie) lub usługi dostarczane klientom (np. mieszkańcom), natomiast procesy obejmują wszystkie działania wspierające, które mają na celu dostarczanie wyrobów lub usług oraz organizację pracy samej jednostki. Uwzględniając specyfikę sektora publicznego GUS (2018) wyróżnił także dodatkowe kategorie innowacji, tj. innowacje w zakresie informacji i komunikacji oraz innowacje w budowaniu i realizacji polityki i strategii.

W typologii innowacji przyjętej przez GUS nie mieszczą się innowacje technologiczne. Stanowi to konsekwencję specyfiki sektora publicznego - dla celów badania GUS przyjął, że sektor publiczny tworzą organizacje, które nie produkują towarów lub usług na sprzedaż po cenach ekonomicznie istotnych, tj. głównie jednostki administracji publicznej, instytucje regulacyjne oraz podmioty, które świadczą usługi publiczne w obszarach edukacji, zdrowia i bezpieczeństwa. Z zakresu sektora wyłączono natomiast przedsiębiorstwa publiczne (GUS, 2018: 22). Tak rozumiany sektor publiczny jest więc raczej odbiorcą innowacji technologicznych, których źródeł upatrywać należy w sektorze przedsiębiorstw (np. w obszarze zdrowia w przemyśle medycznym i farmaceutycznym).

Powyższe definicje innowacji i sektora publicznego przyjęto na potrzeby tego opracowania. W analizie pośrednio uwzględniono innowacje technologiczne, gdyż zdolność do ich wdrażania i upowszechniania stanowi jeden z wymiarów innowacyjności.

\section{Definicja i ramy analityczne innowacyjności sektora publicznego}

Innowacyjność sektora publicznego zdefiniowano jako własność, która stanowi funkcję skłonności (motivation) do podejmowania działań innowacyjnych oraz zdolności (capability) do prowadzenia takich działań, tj. zdolności do konstruktywnego krytycyzmu, uczenia się, przeprojektowywania, adaptacji, upowszechniania itd. Pierwszy parametr determinuje kultura organizacyjna (normy, wartości, przywództwo itp.), a także ryzyko związane z prowadzeniem działań innowacyjnych. Drugi parametr kształtują dostępność zasobów, umiejętność i wiedza oraz przestrzeń do 
prowadzenia działań innowacyjnych. Dodatkowo, wyróżnić można także możliwości (opportunities) prowadzenia działań innowacyjnych, które określane są przez kreatywność, autonomię i współpracę (OECD, 2017: 21). Na potrzeby analizy przyjęto jednak, że możliwości prowadzenia działań innowacyjnych stanowią rozwinięcie zdolności do ich prowadzenia.

Innowacyjność $\mathrm{w}$ powyższym rozumieniu badać można na różnych poziomach zarządzania publicznego. Wpływ czynników instytucjonalnych może się bowiem różnić na poziomie pracowników, zespołów lub komórek organizacyjnych, jednostek sektora, podsektorów czy wreszcie całego sektora. Założenie to znajduje pewne potwierdzenie w danych zebranych przez GUS w ramach ww. badania innowacji w jednostkach sektora publicznego. Przykładowo, choć 42\% badanych komórek organizacyjnych potwierdziło, że przełożeni wyższego szczebla zdecydowanie wspierają próby wdrażania nowych rozwiązań i uczenia się na błędach, to zdecydowaną skłonność przełożonych wyższego szczebla do podjęcia ryzyka poparcia innowacji potwierdziło już tylko 26,9\% badanych komórek organizacyjnych (GUS, 2018: 76). Z pewną ostrożnością można więc wnioskować, że na wyższych poziomach zarządzania publicznego rośnie wpływ uwarunkowań systemowych. Przejawia się on niższym poziomem skłonności do działań innowacyjnych, gdyż wiążą się one z ryzykiem.

\section{Rysunek 1. Bariery innowacyjności na poszczególnych etapach cyklu innowacji}

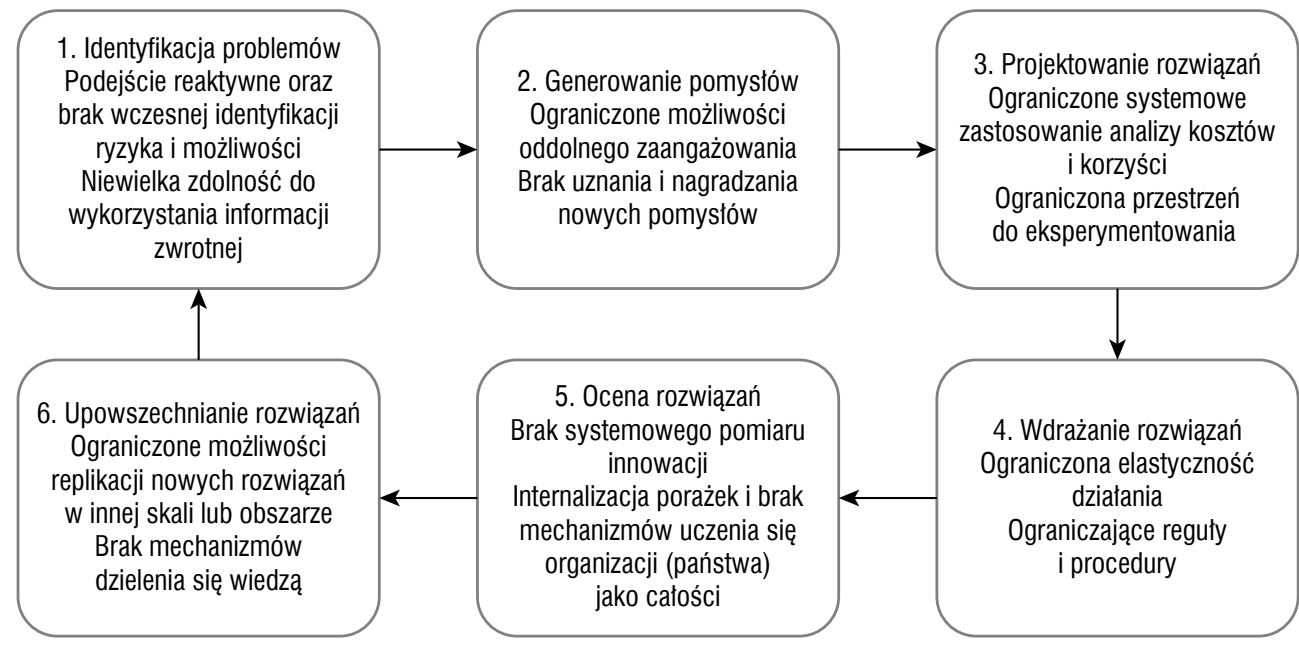

Źródło: układ i tłumaczenie własne na podstawie OECD (2017: 16).

Czynniki determinujące wdrażanie innowacji badać można także przez pryzmat barier, które mogą one stwarzać na poszczególnych etapach cyklu innowacji (rysunek 1). Cykl ten obejmuje sześć etapów, tj.: identyfikację problemów, generowanie 
pomysłów, projektowanie rozwiązań, a następnie ich wdrażanie, ocenę i upowszechnianie (OECD, 2017: 16-17).

Warunkiem rozpoczęcia cyklu innowacji jest identyfikacja potrzeby lub możliwości podjęcia działania innowacyjnego, tj. uznanie istniejącego lub spodziewanego stanu rzeczy za wymagający rozwiązań wykraczających poza te już stosowane. $\mathrm{Na}$ tym etapie ograniczenia wynikać mogą np. z reaktywności systemów zarządzania publicznego, ukierunkowanych na utrzymanie status quo, lub też ich niskiej zdolności do wykorzystania informacji zwrotnej. Identyfikacja potrzeby działania innowacyjnego nie oznacza jeszcze, że nowe rozwiązanie zostanie przygotowane, wdrożone i zreplikowane w większej skali. Rozpoczęty cykl może zostać zatrzymany na każdym $\mathrm{z}$ kolejnych etapów.

Po pierwsze, systemy zatrudniania, wynagradzania i awansowania w sektorze publicznym, o ile nie promują pomysłowości, inicjatywy i mobilności, ograniczać mogą oddolne zaangażowanie pracowników, którzy są głównym źródłem innowacyjnych pomysłów. Po drugie, regulacja wewnątrzadministracyjna może ograniczać przestrzeń do eksperymentowania, już na etapie projektowania rozwiązań eliminując te z nich, które - pomimo swojej potencjalnie wysokiej społecznej użyteczności - wiążą się z wyższym ryzykiem. Ryzyko takie wynikać może np. z konieczności testowania nowych rozwiązań w środowisku rzeczywistym. Po trzecie, wdrażanie wypracowanych rozwiązań - zwłaszcza tych, które wymagają przejściowego wzrostu nakładów ponad poziom bazowy, niezbędny do realizacji zadań bieżących - hamować może ograniczona dostępność lub rozproszenie zasobów.

Wreszcie, niezależnie od wyniku fazy wdrożeniowej, cykl innowacji może zostać przerwany również na etapach dotyczących oceny i upowszechniania. Jednostki sektora mogą wielokrotnie powielać te same niepowodzenia, gdyż awersja do ryzyka - także politycznego - skutkuje ukrywaniem porażek, co utrudnia uczenie się od innych. Słabe systemy wymiany wiedzy oraz fragmentaryczność (silosowość) zarządzania w sektorze publicznym utrudniają również upowszechnianie, tj. replikację $\mathrm{w}$ większej skali lub w innych obszarach funkcjonalnych sektora, rozwiązań wdrożonych $\mathrm{z}$ sukcesem.

\section{Instytucje zarządzania budżetowego determinujące innowacyjność sektora publicznego}

Jak wskazano we wprowadzeniu, wśród systemowych determinant innowacyjności sektora publicznego wyróżnić należy zwłaszcza instytucje zarządzania budżetowego. Z przeprowadzonej analizy wynika bowiem, że skłonność do podejmowania działań 
innowacyjnych determinują m.in. bodźce budżetowe, które kształtują postawy i zachowania sprzyjające - albo nie - poszukiwaniu, wdrażaniu i upowszechnianiu nowych metod i sposobów realizacji zadań publicznych. Zdolność do prowadzenia takich działan zależy natomiast m.in. od dostępności zasobów publicznych, które alokowane są $\mathrm{w}$ ramach budżetowego procesu decyzyjnego.

Analizą objęto dziewięć grup instytucji zarządzania budżetowego, dla jednej z nich (proces budżetowy) wprowadzając dodatkowe elementy uszczegóławiające. W celu pogłębienia analizy, nawiązując do innowacji budżetowych zidentyfikowanych przez Schicka (2013), zastosowano podział tych instytucji na tradycyjne i innowacyjne. Do tych ostatnich zaliczono te instytucje (lub istotne modyfikacje instytucji istniejących), które wprowadzano w ostatnich dekadach w odpowiedzi na rosnące - np. w wyniku zmian demograficznych - napięcia budżetowe lub w celu uzupełnienia luk systemowych, identyfikowanych najczęściej w okresie kryzysów.

Charakter oddziaływania (pozytywny, neutralny, negatywny) poszczególnych grup i typów instytucji zarządzania budżetowego na skłonność do podejmowania oraz zdolność do prowadzenia działań innowacyjnych określono, analizując bodźce wywierane przez te instytucje oraz bariery, które instytucje te mogą stwarzać na poszczególnych etapach cyklu innowacji. Podsumowanie analizy zawiera tabela 1.

Tabela 1. Charakterystyka oddziaływania wybranych instytucji zarządzania budżetowego na innowacyjność sektora publicznego na poszczególnych etapach cyklu innowacji

\begin{tabular}{|c|c|c|c|c|}
\hline \multirow{2}{*}{ Grupy instytucji } & $\mathrm{T}$ & Typy tradycyjne & \multirow{2}{*}{ Charakterystyka oddziaływania } & \multirow{2}{*}{$\begin{array}{l}\text { Etap cyklu } \\
\text { innowacji* }\end{array}$} \\
\hline & I & Typy innowacyjne & & \\
\hline \multirow{2}{*}{$\begin{array}{l}\text { Reguły stabilności } \\
\text { budżetowej }\end{array}$} & $\mathrm{T}$ & $\begin{array}{l}\text { Miękkie ograniczenia } \\
\text { (preferencja do } \\
\text { finansowania długiem) }\end{array}$ & Neutralne & 1 \\
\hline & I & $\begin{array}{l}\text { Twarde ograniczenia } \\
\text { (numeryczne reguły } \\
\text { budżetowe) }\end{array}$ & $\begin{array}{l}\text { Pozytywne: presja budżetowa zwiększa skłonność } \\
\text { do innowacji } \\
\text { W warunkach fragmentacji budżetu zbyt silna } \\
\text { presja może ograniczać zdolność do innowacji }\end{array}$ & $\begin{array}{l}1,2 \\
4,6\end{array}$ \\
\hline \multirow{2}{*}{$\begin{array}{l}\text { Perspektywa } \\
\text { budżetowa }\end{array}$} & $T$ & Roczna & $\begin{array}{l}\text { Negatywne: krótka perspektywa zmniejsza } \\
\text { skłonność i zdolność do niektórych innowacji }\end{array}$ & $3,4,6$ \\
\hline & I & $\begin{array}{l}\text { Wieloletnia } \\
\text { (średniookresowe ramy } \\
\text { budżetowe) }\end{array}$ & $\begin{array}{l}\text { Pozytywne: dłuższa perspektywa zwiększa } \\
\text { skłonność i zdolność do innowacji }\end{array}$ & $2,3,4,6$ \\
\hline \multirow{2}{*}{$\begin{array}{l}\text { Proces budżetowy: } \\
\text { przebieg }\end{array}$} & $T$ & $\begin{array}{l}\text { Strukturyzacja oddolna } \\
\text { (dominacja potrzeb) }\end{array}$ & Neutralne & 1 \\
\hline & I & $\begin{array}{l}\text { Strukturyzacja odgórna } \\
\text { (dominacja celów } \\
\text { budżetowych) }\end{array}$ & $\begin{array}{l}\text { Pozytywne: presja budżetowa zwiększa skłonność } \\
\text { do innowacji }\end{array}$ & $1-4$ \\
\hline
\end{tabular}




\begin{tabular}{|c|c|c|c|c|}
\hline \multirow{2}{*}{ Grupy instytucji } & T & Typy tradycyjne & \multirow{2}{*}{ Charakterystyka oddziaływania } & \multirow{2}{*}{$\begin{array}{l}\text { Etap cyklu } \\
\text { innowacji* }\end{array}$} \\
\hline & 1 & Typy innowacyjne & & \\
\hline \multirow{2}{*}{$\begin{array}{l}\text { Proces budżetowy: } \\
\text { koncentracja }\end{array}$} & $\mathrm{T}$ & $\begin{array}{l}\text { Decyzje programowe } \\
\text { poza procesem } \\
\text { budżetowym }\end{array}$ & $\begin{array}{l}\text { Negatywne: rozproszenie procesów decyzyjnych } \\
\text { zmniejsza zdolność do innowacji }\end{array}$ & 5,6 \\
\hline & 1 & $\begin{array}{l}\text { Decyzje programowe } \\
\text { w procesie budżetowym }\end{array}$ & $\begin{array}{l}\text { Pozytywne: koncentracja procesów decyzyjnych } \\
\text { zwiększa skłonność i zdolność do innowacji }\end{array}$ & $\begin{array}{l}1,2,3 \\
5,6\end{array}$ \\
\hline \multirow[b]{2}{*}{ Podział budżetu } & T & Organizacyjny (jednostki) & Neutralne & $1-6$ \\
\hline & 1 & Programowy (polityki) & $\begin{array}{l}\text { Pozytywne: wspólna architektura systemu } \\
\text { zarządzania publicznego zwiększa skłonność } \\
\text { i zdolność do innowacji }\end{array}$ & $1-6$ \\
\hline \multirow{3}{*}{$\begin{array}{l}\text { Mechanizmy } \\
\text { planowania } \\
\text { i oceny budżetu }\end{array}$} & $\mathrm{T}$ & Historyczne & $\begin{array}{l}\text { Negatywne: inkrementalizm zmniejsza skłonność } \\
\text { i zdolność do innowacji }\end{array}$ & $1,2,3,6$ \\
\hline & I & Automatyczne cięcia & $\begin{array}{l}\text { Pozytywne: presja budżetowa zwiększa skłonność } \\
\text { do innowacji, choć - jeśli w danym obszarze } \\
\text { osiągnięto granicę technologiczną - cięcia mogą } \\
\text { odbywać się kosztem wolumenu ustug }\end{array}$ & $2,3,4,6$ \\
\hline & 1 & Przeglądy wydatków & $\begin{array}{l}\text { Pozytywne: presja budżetowa zwiększa skłonność, } \\
\text { a metoda przeglądów zwiększa zdolność do } \\
\text { innowacji (identyfikacja i upowszechnianie) }\end{array}$ & $1-6$ \\
\hline \multirow{2}{*}{$\begin{array}{l}\text { Mechanizmy } \\
\text { wykonywania } \\
\text { budżetu }\end{array}$} & T & Budżety szczegółowe & $\begin{array}{l}\text { Negatywne: odgórnie określona struktura } \\
\text { nakładów i ograniczenia dotyczące przeniesień } \\
\text { zmniejszają skłonność i zdolność do innowacji }\end{array}$ & 3,4 \\
\hline & 1 & Budżety globalne & $\begin{array}{l}\text { Pozytywne: elastyczność gospodarowania } \\
\text { zwiększa zdolność do innowacji (dobór nakładów, } \\
\text { eksperymentowanie) }\end{array}$ & 3,4 \\
\hline \multirow{2}{*}{$\begin{array}{l}\text { Mechanizmy } \\
\text { kontroli budżetu }\end{array}$} & T & $\begin{array}{l}\text { Kryterium zgodności } \\
\text { nakładów poniesionych } \\
\text { z planem }\end{array}$ & $\begin{array}{l}\text { Negatywne: prymat planu nakładów zmniejsza } \\
\text { skłonność do innowacji (ryzyko działań } \\
\text { niestandardowych) }\end{array}$ & $1,2,3$ \\
\hline & 1 & Kryterium rezultatów & $\begin{array}{l}\text { Pozytywne: ukierunkowanie na rezultaty zwiększa } \\
\text { skłonność i zdolność do innowacji (zachęty do } \\
\text { eksperymentowania, niższa awersja do ryzyka) }\end{array}$ & $1,2,3$ \\
\hline \multirow{2}{*}{$\begin{array}{l}\text { Systemy } \\
\text { informacyjne }\end{array}$} & T & Fragmentaryczne & $\begin{array}{l}\text { Negatywne: fragmentaryczny i ograniczony } \\
\text { charakter (tylko informacja finansowa) zmniejsza } \\
\text { zdolność do innowacji }\end{array}$ & 5,6 \\
\hline & 1 & Całościowe & $\begin{array}{l}\text { Pozytywne: szeroki zakres podmiotowy } \\
\text { i uwzględnienie informacji niefinansowej } \\
\text { zwiększają zdolność do innowacji }\end{array}$ & 5,6 \\
\hline \multirow{2}{*}{$\begin{array}{l}\text { Formy } \\
\text { gospodarowania }\end{array}$} & $\mathrm{T}$ & $\begin{array}{l}\text { Rozdrobnienie i sztywne } \\
\text { typy jednostek } \\
\text { (brutto/netto) }\end{array}$ & $\begin{array}{l}\text { Negatywne: rozproszenie organizacyjne sektora } \\
\text { ogranicza zdolność do innowacji, budżetowanie } \\
\text { brutto ogranicza skłonność do innowacji }\end{array}$ & $3,4,6$ \\
\hline & I & $\begin{array}{l}\text { Konsolidacja jednostek } \\
\text { i ich jednolity typ }\end{array}$ & $\begin{array}{l}\text { Pozytywne: konsolidacja jednostek zwiększa } \\
\text { zdolność do innowacji, rozrachunek gospodarczy } \\
\text { (budżetowanie netto) zwiększa skłonność do } \\
\text { innowacji }\end{array}$ & $3,4,6$ \\
\hline
\end{tabular}

* Etapy cyklu innowacji: 1 - identyfikacja problemów, 2 - generowanie pomysłów, 3 - projektowanie rozwiązań, 4 - wdrażanie rozwiązań, 5 - ocena rozwiązań, 6 - upowszechnianie rozwiązań.

Źródło: opracowanie własne. 


\section{Charakterystyka oddziaływania tradycyjnych instytucji zarządzania budżetowego}

Tradycyjne instytucje zarządzania budżetowego nie sprzyjają innowacyjności sektora publicznego. Miękkie ograniczenia budżetowe (preferencja do finansowania długiem, deficit bias) oraz inkrementalny (inaczej: przyrostowy, historyczny) charakter planowania budżetowego ograniczają tarcia wynikające z konieczności osiągnięcia - w ramach napiętego kalendarza budżetowego - politycznego kompromisu co do poziomu i struktury wydatków. Nie skłaniają one jednak do poszukiwania nowych, bardziej produktywnych metod realizacji zadań publicznych. Oddolny charakter planowania, który zakłada prymat potrzeb, nie sprzyja także selekcjonowaniu i priorytetyzacji takich metod.

Negatywny wpływ na innowacyjność w sektorze publicznym mają krótki horyzont planowania budżetowego oraz rygorystyczne mechanizmy wykonywania i kontroli budżetu. Roczny horyzont planowania ogranicza skłonność do innowacji o okresie wdrażania dłuższym niż rok. Dzieje się tak zwłaszcza wtedy, gdy innowacje te wymagają wzrostu nakładów (ponad poziom bazowy, niezbędny do bieżącej realizacji zadań) w pierwszym roku wdrażania, a efekty budżetowe (oszczędności) widoczne są dopiero w latach kolejnych. Tradycyjne mechanizmy kontrolne opierają się na szczegółowym planowaniu i rozliczaniu nakładów, co ogranicza pole do eksperymentowania. Wzmacniają one również awersję do ryzyka wynikającego z odchodzenia od sprawdzonych metod działania.

Wreszcie, negatywny wpływ na zdolność do innowacji wywierają także tradycyjne systemy informacyjne oraz rozproszenie organizacyjne sektora publicznego. Te pierwsze nie dostarczają bowiem kompleksowej informacji niefinansowej o rezultatach działań innowacyjnych, niezbędnej do oceny ich skuteczności. Fragmentacja sektora utrudniać może natomiast uczenie się jednostek sektora publicznego od siebie i upowszechnianie innowacji. Barierę dla upowszechniania stanowić mogą zwłaszcza niewystarczające, bo rozproszone pomiędzy liczne jednostki, zasoby niezbędne do replikacji innowacji w większej skali.

\section{Charakterystyka oddziaływania innowacyjnych instytucji zarządzania budżetowego}

Innowacyjne instytucje zarządzania budżetowego - co do zasady - charakteryzują się natomiast pozytywnym wpływem na innowacyjność sektora publicznego. Skłonność do innowacji pobudzają zwłaszcza numeryczne reguły budżetowe, które 
bezpośrednio lub pośrednio ograniczają poziom wydatków publicznych. Dzieje się tak szczególnie w przypadku odgórnej strukturyzacji procesu budżetowego. Prymat celów budżetowych i związana $\mathrm{z}$ tym presja budżetowa (odgórnie ograniczona dostępność zasobów) stanowią bowiem bodźce do poszukiwania alternatywnych metod realizacji zadań publicznych. Efekt ten wzmacniać mogą również automatyczne cięcia wydatków (inaczej dywidenda efektywnościowa) oraz przeglądy wydatków.

Mechanizm automatycznych cięć opiera się na założeniu, że w sferze świadczenia usług publicznych możliwy jest stały - choć niewielki - wzrost produktywności. W celu indukowania tego wzrostu limity wydatków operacyjnych jednostek organizacyjnych systematycznie obniża się o około 1-2\% rocznie, co ma zwiększać skłonność do poszukiwania i wprowadzania zmian technologicznych, organizacyjnych, współdzielenia zasobów itp. Zbliżone skutki wywierać mogą przeglądy wydatków. Ich celem jest identyfikacja oszczędności wynikających np. z ograniczenia lub eliminacji polityk, programów czy instrumentów, które się zdezaktualizowały, cechują się niską skutecznością lub efektywnością.

Dla porządku odnotować należy, że nadmierna presja budżetowa wywierać może negatywny wpływ na innowacyjność. Będzie tak zwłaszcza wtedy, gdy w danym obszarze osiągnięto granicę technologiczną lub jest ona bardzo blisko, a także w warunkach ograniczonej zdolności do prowadzenia działań innowacyjnych, np. w wyniku dużej fragmentacji budżetu. Presja budżetowa skutkować może wtedy ograniczeniem ilości lub pogorszeniem jakości świadczonych usług.

Pozytywny wpływ na skłonność do innowacji w sektorze publicznym wywierają natomiast wieloletnia perspektywa planowania budżetowego oraz mechanizmy kontroli budżetu oparte na kryterium rezultatów. Wieloletnia perspektywa budżetowania łagodzi lub eliminuje bariery, które wynikają z zasady roczności budżetu - w średniookresowych ramach budżetowych widoczne są bowiem całościowe skutki budżetowe działań innowacyjnych. Jest to istotne zwłaszcza w odniesieniu do oszczędności, które w perspektywie rocznej są często niewidoczne, gdyż występują dopiero po przejściowym wzroście nakładów w pierwszym okresie wdrażania. Ramy sprzyjają więc projektowaniu i wdrażaniu innowacji o okresie realizacji dłuższym niż rok. Z kolei mechanizmy kontroli budżetu oparte na kryterium rezultatów zachęcają kierowników jednostek do eksperymentowania i zmniejszają ich awersję do ryzyka.

Innowacyjne instytucje zarządzania budżetowego wywierają również pozytywny wpływ na zdolność sektora publicznego do identyfikowania, wdrażania i upowszechniania innowacji. Zdolność tę kształtują zwłaszcza skoncentrowany budżetowy proces decyzyjny, który obejmuje również decyzje programowe dotyczące kierunków, celów i form interwencji publicznej, oraz wspólna architektura systemowa zarządzania publicznego. Przejawem tej ostatniej jest m.in. programowy podział budżetu, 
charakterystyczny dla modelu budżetowania opartego na programach (programme budgeting). Podział taki koresponduje z obszarami funkcjonalnymi państwa i politykami publicznymi, co umożliwia powiązanie zarządzania nimi z budżetowaniem oraz synchronizację cyklu zarządzania politykami z cyklem budżetowym. Wspólne kanały przepływu informacji o celach, zadaniach, zasobach i rezultatach umożliwiają np. włączenie do budżetowania informacji zwrotnej o charakterze niefinansowym, w tym o skuteczności działań innowacyjnych wdrażanych w ramach poszczególnych działów polityki. Informacja taka dostępna jest $\mathrm{z}$ reguły $\mathrm{w}$ średnim okresie, więc zdolność sektora publicznego do jej wykorzystania kształtują m.in. średniookresowe ramy budżetowe.

Wreszcie, pozytywny wpływ na zdolność jednostek sektora publicznego do wdrażania i upowszechniania innowacji mają także elastyczność zarządzania operacyjnego oraz konsolidacja struktur organizacyjnych. Budżety globalne umożliwiają kierownikom jednostek samodzielne kształtowanie struktury nakładów adekwatnie do stosowanych metod realizacji zadań publicznych. Zaś większy budżet - w rozumieniu liczby jednostek i zadań publicznych nim objętych - oznacza większe możliwości realokacji oraz wdrażania i upowszechniania nowych rozwiązań.

\section{Typologia systemów zarządzania budżetowego}

Charakterystyka oddziaływania poszczególnych instytucji zarządzania budżetowego na innowacyjność sektora publicznego nie oddaje w pełni występujących w tym zakresie współzależności. W ramach konkretnego systemu (zespołu instytucji) zarządzania budżetowego oddziaływanie poszczególnych instytucji może się wzajemnie wzmacniać lub znosić. Aktywowanie określonego oddziaływania wymagać może także odpowiedniego kształtu instytucji pozornie od siebie niezależnych. Przykładowo, pozytywny wpływ reguł budżetowych na innowacyjność sektora publicznego wymaga odpowiedniego podziału budżetu i organizacji sektora. Bodźce i zachęty budżetowe do podejmowania działań innowacyjnych spełniać mogą bowiem swoją funkcję tylko w warunkach odpowiedniej zdolności do prowadzenia takich działań.

W kontekście budżetowym poziom innowacyjności sektora publicznego zależy również od tego, czy i w jakim stopniu innowacyjność jest przedmiotem lub narzędziem polityki budżetowej. Podejście pozytywne zakłada, że w warunkach ograniczeń dochodowych poszukiwanie i wdrażanie nowych, bardziej produktywnych metod produkcji publicznej sprzyja utrzymaniu optymalnego wolumenu dóbr i usług publicznych oraz poprawie zagregowanych wyników budżetowych. Władze budżetowe dążą więc do indukowania innowacyjności z wykorzystaniem instrumentów 
budżetowych. Podejście neutralne oznacza, że władze budżetowe nie rozpoznają budżetowego znaczenia innowacyjności i nie widzą potrzeby oddziaływania na ten parametr. Podejście negatywne skutkuje natomiast ograniczaniem innowacyjności, przy czym negatywnie wartościowane są raczej normy i zachowania, które determinują innowacyjność, niż innowacyjność jako taka.

Uwzględniając powyższe, systemy zarządzania budżetowego podzielić można na hamujące, neutralne lub pobudzające innowacyjność sektora publicznego (OECD, 2017: 131). Typologię systemów zarządzania budżetowego, dla której systemem bazowym jest system tradycyjny, przedstawia tabela 2 .

Tabela 2. Typy systemów zarządzania budżetowego wg wpływu na innowacyjność sektora publicznego

\begin{tabular}{|c|c|c|c|}
\hline Grupa & Typ & $\begin{array}{l}\text { Oddziaływanie instytucji } \\
\text { zarządzania budżetowego }\end{array}$ & Postawa władz budżetowych \\
\hline \multirow[t]{2}{*}{ Hamujące } & $\begin{array}{l}\text { Sceptyczny } \\
\text { (negatywny) }\end{array}$ & $\begin{array}{l}\text { Ograniczające (bariery } \\
\text { większe niż w systemie } \\
\text { tradycyjnym) }\end{array}$ & $\begin{array}{l}\text { Negatywna, czynniki sprzyjające } \\
\text { innowacyjności są aktywnie ograniczane przez } \\
\text { władze budżetowe }\end{array}$ \\
\hline & $\begin{array}{l}\text { Restrykcyjny } \\
\text { (tradycyjny) }\end{array}$ & Ograniczające (bariery) & $\begin{array}{l}\text { Neutralna, innowacyjność nie jest } \\
\text { przedmiotem zainteresowania władz } \\
\text { budżetowych }\end{array}$ \\
\hline \multirow[t]{2}{*}{ Neutralne } & $\begin{array}{l}\text { Nieresponsywny } \\
\text { (neutralny negatywnie) }\end{array}$ & Mieszane & $\begin{array}{l}\text { Neutralna, innowacyjność nie jest } \\
\text { przedmiotem zainteresowania władz } \\
\text { budżetowych }\end{array}$ \\
\hline & $\begin{array}{l}\text { Akomodujący } \\
\text { (neutralny pozytywnie) }\end{array}$ & Mieszane lub sprzyjające & $\begin{array}{l}\text { Neutralna, innowacyjność nie jest } \\
\text { przedmiotem oddziaływania władz } \\
\text { budżetowych }\end{array}$ \\
\hline Pobudzające & Stymulujący & Sprzyjające & $\begin{array}{l}\text { Pozytywna, innowacyjność jest przedmiotem } \\
\text { aktywnego oddziaływania władz budżetowych }\end{array}$ \\
\hline
\end{tabular}

Źródło: opracowanie własne na podstawie OECD (2017: 131-132).

Systemy zarządzania budżetowego hamujące innowacyjność charakteryzują się dużą liczbą szczegółowych regulacji dotyczących gospodarowania zasobami publicznymi, naciskiem na planowanie i rozliczanie nakładów oraz kontrolą opartą na kryterium zgodności. W tej grupie mieszczą się systemy sceptyczne, w których aktywnie tworzy się bariery dla czynników sprzyjających innowacyjności, oraz systemy tradycyjne, w których istnieją bariery dla innowacyjności, jednak sama innowacyjność nie jest przedmiotem zainteresowania władz budżetowych.

Systemy zarządzania budżetowego neutralne podzielić można na neutralne negatywnie (nieresponsywne) oraz neutralne pozytywnie (akomodujące). W obu typach systemów instytucje zarządzania budżetowego mogą sprzyjać innowacyjności, jednak sama innowacyjność nie jest przedmiotem (odpowiednio) zainteresowania lub oddziaływania władz budżetowych. Systemy nieresponsywne całkowicie ignorują 
więc budżetowy potencjał innowacji, natomiast systemy akomodujące zapewniają jednostkom pewną przestrzeń do innowacji.

Ostatnią grupę tworzą systemy, w których władze budżetowe dostrzegają znaczenie innowacyjności sektora publicznego dla zagregowanych wyników budżetowych i świadomie oddziałują na ten parametr.

\section{Ocena instytucji zarządzania budżetowego podsektora rządowego w Polsce}

Wyniki analizy oddziaływania instytucji zarządzania budżetowego na innowacyjność sektora publicznego wykorzystano do oceny systemu zarządzania budżetowego podsektora rządowego w Polsce. Przedmiotem tej oceny był kształt podstawowych instytucji tego systemu. Pominięto więc klauzule, które zawieszają stosowanie określonych mechanizmów w stanach nadzwyczajnych. Nie oceniano również kierunków polityki budżetowej prowadzonej przez konkretne władze budżetowe.

System zarządzania budżetowego podsektora rządowego w Polsce charakteryzuje się względnie twardymi ograniczeniami budżetowymi. Dostępność zasobów ogranicza reguła wydatkowa (art. 112a Ustawy o finansach publicznych, UFP). Reguła umożliwia wyznaczenie kwoty wydatków i nieprzekraczalnego limitu wydatków, które determinują łączny limit wydatków części krajowej budżetu państwa oraz limity wydatków poszczególnych części budżetowych. Te ostatnie wielkości, z zastrzeżeniem przeniesień dopuszczalnych w ramach łącznego limitu wydatków budżetu państwa, mają charakter nieprzekraczalny (art. 52 ust. 1 pkt 2 UFP). Zasada ta wydaje się dość restrykcyjna na tle systemów budżetowych innych państw (OECD, 2014; 2019).

Zasadniczo twarde ograniczenia budżetowe powinny sprzyjać innowacyjności sektora publicznego. Potencjalnie pozytywny wpływ reguły wydatkowej na innowacyjność częściowo neutralizuje jednak jej konstrukcja. Reguła nie obejmuje bowiem wszystkich jednostek i funduszy - ograniczona rozpiętość reguły rodzić może pokusę łagodzenia presji budżetowej przez tworzenie funduszy i jednostek sektora wyłączonych z zakresu jej obowiązywania. Ponadto, reguła zakłada de facto, że ciężar niezbędnych dostosowań spoczywa głównie na części krajowej budżetu państwa. Ze względu na dużą sztywność wydatków tego agregatu presja budżetowa wywierać może negatywny wpływ na innowacyjność, m.in. ograniczając zdolność jednostek sektora publicznego objętych regułą do wdrażania i upowszechniania innowacji.

Analiza instytucji, zasad i praktyk budżetowych w podsektorze rządowym pokazuje, że nie spełniają one warunków pozytywnego oddziaływania na innowacyjność, które dotyczą strukturyzacji i koncentracji procesu budżetowego, integracji systemu 
zarządzania budżetowego z innymi systemami zarządzania publicznego czy też spójnych bodźców budżetowych.

Skłonność do podejmowania działań innowacyjnych jest ograniczana przez roczny horyzont budżetowania oraz zasady planowania i prognozowania budżetowego, które faworyzują przyrostowość i istniejącą strukturę wydatków (zob. np. \$3 Rozporządzenia Ministra Finansów z 28 stycznia 2019 r. w sprawie szczegółowego sposobu, trybu i terminów opracowania materiałów do projektu ustawy budżetowej). Do poszukiwania nowych metod realizacji zadań publicznych nie zachęca także kontrola wykonania budżetu oparta głównie na kryterium formalnej zgodności wykonania z planem. Instrumenty budżetowania ukierunkowanego na wyniki (np. układ zadaniowy) wykorzystywane są tylko w celach prezentacyjnych.

Zdolność do prowadzenia działań innowacyjnych ograniczają m.in. oddolny charakter planowania budżetowego oraz rozdzielność tego procesu i rządowych prac programowo-legislacyjnych. Obecny podział budżetu nie odzwierciedla również w pełni podziału kompetencji w administracji rządowej (Rada Ministrów, 2016). W konsekwencji budżetowanie i zarządzanie politykami publicznymi nie są ze sobą powiązane w stopniu, który umożliwiałby identyfikowanie i upowszechnianie innowacji w ramach budżetowania. Ograniczone są również możliwości wykorzystania w tym celu niefinansowej informacji zwrotnej (tj. informacji o efektach prowadzonych działań) gromadzonej w innych podsystemach zarządzania publicznego. Próby wykorzystania takiej informacji do prognozowania wydatków na kolejne lata nie przyniosły oczekiwanych rezultatów (zob. np. $\$ 3$ ust. 2 Rozporządzenia Ministra Rozwoju i Finansów z 13 czerwca 2017 r. w sprawie szczegółowego sposobu, trybu i terminów opracowania materiałów do projektu ustawy budżetowej, który przewidywał ustalanie wyjściowych kwot wydatków na kolejne lata z wykorzystaniem wyników analizy racjonalności i efektywności, rozwoju nowoczesnych technologii oraz rekomendacji z przeglądów wydatków; wytyczne takie nie zostały zamieszczone w Rozporządzeniu z 2019 r.).

Zdolność do wdrażania działań innowacyjnych i upowszechniania innowacji jest również ograniczana przez fragmentację budżetu państwa oraz rozproszenie organizacyjne podsektora rządowego. W podsektorze rządowym budżetowym przykład stanowi administracja zespolona, która - choć realizuje zadania ministrów kierujących poszczególnymi działami administracji rządowej - budżetowo podzielona jest pomiędzy wojewodów (równorzędnych dysponentów części budżetowej 85 - Budżety wojewodów). O rozproszeniu w podsektorze rządowym pozabudżetowym świadczy natomiast rosnąca liczba jednostek i funduszy. W obu przypadkach dochodzi do dekoncentracji zasobów, co utrudnia reagowanie na bodźce budżetowe i wzajemne uczenie się jednostek. 
Ustalenia te pozwalają zaliczyć system zarządzania budżetowego podsektora rządowego w Polsce do typu tradycyjnego (według typologii OECD). Liczne instytucje budżetowe ograniczają skłonność do podejmowania lub zdolność do prowadzenia działań innowacyjnych, a innowacyjność nie stanowi parametru, który byłby przedmiotem zainteresowania lub oddziaływania władz budżetowych.

$* * *$

Z przeprowadzonej analizy wynika, że instytucje zarządzania budżetowego w znaczący sposób oddziałują na obydwie składowe innowacyjności sektora publicznego. Skłonność do podejmowania działań innowacyjnych kształtowana jest przez bodźce budżetowe, tj. ograniczenia (np. presja budżetowa, która wynika $\mathrm{z}$ reguł budżetowych lub automatycznych cięć) czy zachęty (np. w formie możliwości zatrzymywania przez jednostki części oszczędności wygospodarowanych dzięki innowacjom). Zdolność do wdrażania i upowszechniania działań innowacyjnych kształtowana jest zaś m.in. przez autonomię zarządzania operacyjnego, $w$ tym $w$ odniesieniu do przydzielonych zasobów publicznych, a także dostępność tych zasobów. Wdrażanie nowych rozwiązań wymaga często przejściowego wzrostu nakładów (ponad poziom bazowy, niezbędny do bieżącej realizacji zadań), który przynosi oszczędności dopiero w kolejnych latach. Zdolności do innowacji sprzyjają więc średniookresowe ramy budżetowe, które wydłużają perspektywę planowania budżetowego.

Ze względu na liczne współzależności wpływ poszczególnych instytucji zarządzania budżetowego na poziom innowacyjności sektora publicznego rozpatrywać należy w ujęciu systemowym, tj. w ramach konkretnego zespołu tych instytucji (systemu zarządzania budżetowego) lub - szerzej - w ramach całego systemu zarządzania publicznego. Oddziaływania różnych instytucji mogą się bowiem wzajemnie wzmacniać lub znosić, a aktywacja określonego oddziaływania wymagać może konkretnego kształtu kilku instytucji. W szczególności bodźce budżetowe spełniać mogą swoją funkcję tylko w warunkach odpowiedniej zdolności do prowadzenia działań innowacyjnych.

Wreszcie, niezależnie od budżetowych uwarunkowań systemowych, poziom innowacyjności sektora publicznego zależy także od tego, na ile władze budżetowe - rozpoznając budżetowe znaczenie innowacyjności - oddziałują na innowacyjność, wykorzystując do tego instrumenty budżetowe. Największy potencjał mają w tym zakresie budżetowe mechanizmy „uczenia się" w sektorze publicznym, tj. mechanizmy planowania budżetowego oraz oceny wydatków. Pobudzanie innowacyjności wymaga bowiem, by mechanizmy te umożliwiały identyfikację wdrażanych lub planowanych innowacji, ich ocenę i selekcjonowanie (na podstawie kryteriów dotyczących faktycznych lub spodziewanych korzyści) oraz upowszechnianie. Mechanizmy 
te, $\mathrm{z}$ uwagi na napięty kalendarz budżetowych prac planistycznych, stanowić mogą jednak wąskie gardło, ograniczające innowacyjność sektora publicznego. Gromadzenie i przetwarzanie $w$ ramach procesu budżetowego informacji zwrotnej o charakterze niefinansowym wiąże się z ryzykiem jego przeciążenia (Shaw, 2016). Przeciwdziałać temu może integracja procesów budżetowania i zarządzania politykami publicznymi przy użyciu wspólnej architektury systemowej (np. programowy podział budżetu państwa). Architektura taka pozwala bowiem na bezpośrednie włączenie do budżetowania informacji zwrotnej o charakterze niefinansowym pozyskiwanej z wykorzystaniem rozwiązań ewaluacyjnych i sprawozdawczych stosowanych w ramach poszczególnych polityk sektorowych.

Zastosowanie ustaleń analitycznych do oceny systemu zarządzania budżetowego podsektora rządowego w Polsce pozwala sformułować propozycje dotyczące pożądanych kierunków rozwoju tego systemu. Po pierwsze, wskazane jest dążenie do ścisłej koncentracji publicznych procesów decyzyjnych w ramach procesu budżetowego oraz do integracji różnych podsystemów zarządzania (strategicznego, budżetowego i operacyjnego) przy użyciu wspólnej architektury zarządzania publicznego. Rdzeń systemu stanowić powinny: programowy podział budżetu oraz elementy zarządzania i budżetowania ukierunkowanego na wyniki, umożliwiające - $\mathrm{w}$ ramach procesu budżetowego - transmisję celów z poziomu strategicznego na operacyjny oraz wykorzystanie w budżetowaniu niefinansowej informacji zwrotnej.

Po drugie, w celu pobudzania skłonności do innowacji wskazane wydają się przebudowa i uzupełnienie systemu reguł budżetowych. Poszerzeniu rozpiętości istniejących reguł budżetowych towarzyszyć powinno ich uzupełnienie o niewielkie (na poziomie około 1\%) automatyczne cięcia niektórych kategorii wydatków operacyjnych, odzwierciedlające zakładany wzrost produktywności sektora publicznego. Bodźce budżetowe należy uzupełniać poprzez przeniesienie ciężaru kontroli na osiągnięcia (rozliczalność) oraz mechanizmy partycypacji dysponentów środków publicznych w wygospodarowanych oszczędnościach.

Po trzecie, w celu zapewnienia zdolności do innowacji wskazane może być uelastycznienie zasad gospodarki finansowej jednostek budżetowych. Rozważenia wymaga zwłaszcza wprowadzenie elementów gospodarowania na podstawie zasady netto w zakresie działalności tych jednostek, która ma lub może mieć charakter zbliżony do rynkowego. Wskazana byłaby również konsolidacja jednostek organizacyjnych sektora w kierunku utworzenia jednostek dużych, obejmujących całe administracje, o większym potencjale instytucjonalnym i finansowym.

Rekomendowane działania mogą być wprowadzane oddzielnie, jednak - ze względu na liczne współzależności - większe korzyści przynieść może ich łączne wdrożenie. Tylko wtedy możliwe jest bowiem ukształtowanie spójnego systemu 
bodźców budżetowych pobudzających skłonność do podejmowania działań innowacyjnych oraz adekwatnej zdolności jednostek sektora do prowadzenia takich działań.

Wdrożenie proponowanych rozwiązań powinno się przyczynić również do odblokowania potencjału innowacyjnego podsektora rządowego w Polsce, a także wzmocnienia adaptatywności i responsywności systemu zarządzania publicznego, niezbędnych ze względu na rosnącą niepewność i złożoność współczesnych wyzwań.

\section{Bibliografia}

GUS (Główny Urząd Statystyczny) (2018). Badanie innowacji w wybranych jednostkach administracji publicznej w Polsce. Warszawa: Zakład Wydawnictw Statystycznych.

Hawkesworth, I., von Trapp, L., Nielsen, D. (2011). Performance Budgeting in Poland: An OECD Review. OECD Journal on Budgeting, 11(1): 7-57. DOI: 10.1787/budget-v11-1-en.

OECD (Organisation for Economic Co-operation and Development) (2014). Budgeting Practices and Procedures in OECD Countries. Paris: OECD Publishing, DOI: 10.1787/978926405 9696-en.

OECD (Organisation for Economic Co-operation and Development) (2015). OECD Innovation strategy 2015: An agenda for policy action. Meeting of the OECD Council at Ministerial Level, Paris, 3-4 June 2015, https://www.oecd.org/sti/oecd-innovation-strategy-2015-cmin2015-7.pdf (dostęp: 20.09.2020).

OECD (Organisation for Economic Co-operation and Development) (2017). Fostering Innovation in the Public Sector. Paris: OECD Publishing, DOI: 10.1787/9789264270879-en.

OECD (Organisation for Economic Co-operation and Development) (2019). Budgeting and Public Expenditures in OECD Countries 2019. Paris: OECD Publishing, DOI: 10.1787/ 9789264307957-en.

OECD (Organisation for Economic Co-operation and Development), Eurostat (2018). Oslo Manual 2018: Guidelines for Collecting, Reporting and Using Data on Innovation, $4^{\text {th }}$ ed., Paris, Luxembourg: OECD Publishing, Eurostat. DOI: 10.1787/9789264304604-en.

Rada Ministrów (2016). Założenia reform system budżetowego. Warszawa: Rada Ministrów.

Schick, A. (2013). Reflections on two decades of public financial management reforms. W: Public financial management and its emerging architecture: 21-76, M. Cangiano, T. Curristine, M. Lazare (red.). Washington, DC: International Monetary Fund.

Shaw, T. (2016). Performance budgeting practices and procedures. OECD Journal on Budgeting, 15(1): 65-136, DOI: 10.1787/budget-v15-1-en.

Unless stated otherwise, all the materials are available under the Creative Commons Attribution 4.0 International license. Some rights reserved to SGH Warsaw School of Economics.

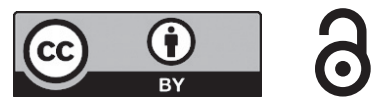

